\title{
Fermentative Volatile Production in Relation to Carbon Dioxide-induced Flesh Browning in 'Fuji' Apple
}

\author{
Richard K. Volz ${ }^{1}$, William V. Biasi, and Elizabeth J. Mitcham \\ Department of Pomology, University of California, Davis, CA 95616
}

Additional index words. fermentation, controlled atmosphere, injury, damage,

Malus $\times$ domestica, acetaldehyde, ethanol, ethyl acetate

\begin{abstract}
Apple (Malus $\times$ domestica Borkh., cv. Fuji) fruit were harvested from two California orchards 190 and 210 days after full bloom and from an additional three orchards at 190 days after full bloom. Fruit were immediately exposed to 20 or $50 \mathrm{kPa} \mathrm{CO}$ in air at $20^{\circ} \mathrm{C}$. Area of flesh browning and tissue ethanol, acetaldehyde, and ethyl acetate concentrations for individual fruit were determined immediately before exposure and after 3 and 7 days $(20 \mathrm{kPa})$ or 1 and 3 days $(50 \mathrm{kPa})$ exposure to $\mathrm{CO}_{2}$. Area of flesh browning and concentrations of all compounds increased with increasing duration of exposure to high $\mathrm{CO}_{2}$, were greater in response to $50 \mathrm{kPa}$ than to $20 \mathrm{kPaCO}$, and were greater for fruit harvested later in the season. For individual orchards and for individual fruit within most orchards, greater flesh browning was associated with higher acetaldehyde concentrations after 7 days exposure to $20 \mathrm{kPa} \mathrm{CO}_{2}$ or 3 days exposure to $50 \mathrm{kPa} \mathrm{CO}_{2}$. Similarly, flesh browning was positively correlated with ethanol concentrations after 7 days at $20 \mathrm{kPa} \mathrm{CO}$, but was not related to tissue ethyl acetate concentrations at either $\mathrm{CO}_{2}$ partial pressure. However, higher production of ethanol, acetaldehyde, or ethyl acetate relative to flesh browning occurred during exposure to $50 \mathrm{kPa}$ than to $20 \mathrm{kPa} \mathrm{CO}$. This suggests that the relationship between accumulation of these compounds and $\mathrm{CO}_{2}$-induced flesh browning in 'Fuji' is not simply causal.
\end{abstract}

Elevated $\mathrm{CO}_{2}$ partial pressure retards senescence and maintains fruit quality during storage of many fruit and vegetable commodities, and is therefore a valuable component of controlled-atmosphere (CA) and modified-atmosphere (MA) storage. For apple, the use of high $\mathrm{CO}_{2}$ in such storage systems is limited by the risk of damage to fruit, and recommended partial pressures in CA storage, for instance, usually do not exceed $5 \mathrm{kPa}$ (Kupferman, 1997). 'Fuji' apples grown in California are particularly sensitive to $\mathrm{CO}_{2}$ gas used in CA storage (Volz et al., 1998). Flesh browning exacerbated by $\mathrm{CO}_{2}$ injury has been observed in some lots of fruit held under CA with $\mathrm{CO}_{2}$ partial pressures as low as $0.4 \mathrm{kPa}$ (Grant et al., 1996). In 'Fuji' (Volz et al., 1998), 'McIntosh' (Bramlage et al., 1977), and 'Golden Delicious' (Meheriuk, 1977), fruit susceptibilities to $\mathrm{CO}_{2}$ partial pressures used in $\mathrm{CA}(1-5 \mathrm{kPa})$, as well as to much higher partial pressures (>10 kPa) can vary according to harvest date, orchard, and season. Although the cause of this variability in fruit response is unknown for 'Fuji', it may be due to differing tissue sensitivities to $\mathrm{CO}_{2}$ (Volz et al., 1998).

Received for publication 27 Oct. 1997. Accepted for publication 2 July 1998. The cost of publishing this paper was defrayed in part by the payment of page charges. Under postal regulations, this paper therefore must be hereby marked advertisement solely to indicate this fact.

${ }^{1}$ Visiting Scientist. Permanent address: Horticulture and Food Research Institute of New Zealand, Hawkes Bay Research Center, Private Bag 1401, Havelock North, New Zealand.
Many commodities accumulate ethanol and acetaldehyde when exposed to high $\mathrm{CO}_{2}$, and this has often been associated with tissue browning and cell death (Kader, 1986; Lidster et al., 1990). High levels of $\mathrm{CO}_{2}$ divert carbon from the Krebs cycle to the fermentative pathway whereby pyruvate is converted to acetaldehyde and ethanol (Ke et al., 1993). Exposure of fruit of some apple cultivars to high $\mathrm{CO}_{2}$ $(\geq 20 \mathrm{kPa})$ can result in rapid accumulation of acetaldehyde and ethanol within the tissue (Pesis et al., 1994; Thomas, 1925, 1929); however, relationships between these compounds and damage are unclear.

Similarly, high concentrations of ethanol and acetaldehyde can be induced and tissue damage can sometimes occur under hypoxic conditions, although there is considerable debate as to the cause(s) of damage and the roles of ethanol and acetaldehyde under anaerobiosis (Perata and Alpi, 1993). For instance, ethanol and acetaldehyde have been induced in apple under very low $\mathrm{O}_{2}$ atmospheres with no accompanying damage (Blanpied and Jozwiak, 1993; Ke and Kader, 1992; Ke et al., 1990; Patterson and Nichols, 1988). Smagula and Bramlage (1977), in reviewing past literature, concluded that acetaldehyde accumulation was probably a result rather than a cause of tissue injury, although they acknowleged that deficiencies in analytical methods may have obscured results.

A relationship between flesh browning and production of ethanol and acetaldehyde in 'Fuji' as induced by high $\mathrm{CO}_{2}$ partial pressures has not been demonstrated. Recently, we found that individual 'Fuji' fruit that had browned, in an atmosphere of $2 \mathrm{kPa} \mathrm{CO}_{2}$ and $2 \mathrm{kPa} \mathrm{O}_{2}$ at 0 ${ }^{\circ} \mathrm{C}$ after 17 weeks, had higher ethanol and acetaldehyde production than those not browned, but stored in the same atmosphere (unpublished data). Our objective in the following study was to determine and compare relationships between flesh browning and ethanol, acetaldehyde, and ethyl acetate production for 'Fuji' during exposure to $\mathrm{CO}_{2}$. Because of the sporadic occurrence of damage in 'Fuji' fruit exposed to the low $\mathrm{CO}_{2}$ atmospheres typically used in CA (Grant et al., 1995; Volz et al., 1998), this study employed high $\mathrm{CO}_{2}$ partial pressures at ambient temperatures to ensure rapid development of injury.

\section{Materials and Methods}

Fruit from 5 two-tree plots were harvested 190 (1-5 Oct.) and $210 \mathrm{~d}$ after full bloom (DAFB) from each of two 'Fuji' orchards located in the San Joaquin Valley, Calif. Fruit were also harvested from 5 two-tree plots at 190 DAFB from an additional three 'Fuji' orchards.

The day following harvest, fruit were sorted and 10 fruit per orchard (two fruit per plot) were placed into each of eight 19-L glass jars. The jars were connected to a humidified flowthrough gas system $\left(300 \mathrm{~mL} \cdot \mathrm{min}^{-1}\right)$ in which the $\mathrm{CO}_{2}$ partial pressure was $50 \mathrm{kPa}$ (balance $=10.3 \mathrm{kPaO}_{2}+38.6 \mathrm{kPa} \mathrm{N}_{2}+2.4 \mathrm{kPa} \mathrm{H}_{2} \mathrm{O}$ ) for four jars, or $20 \mathrm{kPa}$ (balance $=16.6 \mathrm{kPa} \mathrm{O}_{2}+$ $62.3 \mathrm{kPa} \mathrm{N}_{2}+2.4 \mathrm{kPa} \mathrm{H}_{2} \mathrm{O}$ ) for the remaining four jars, all at $20^{\circ} \mathrm{C}$. In addition, from the two orchards that were harvested twice, five fruit per harvest date were sampled immediately before exposure to high $\mathrm{CO}_{2}$. Fruit were exposed to $50 \mathrm{kPa} \mathrm{CO}$ for 1 and $3 \mathrm{~d}$, and to 20 $\mathrm{kPaCO}$ for 3 and $7 \mathrm{~d}$. Two jars were removed for each atmosphere at the completion of each exposure period. Each fruit was then sliced transversely into five sections and assessed for the proportion of flesh area that showed browning. In addition, five fruit were selected at random from each jar, and a 10 -mm-thick equatorial slice was cut from the equator of each fruit. Also, from each of the two orchards harvested twice, five fruit were sliced immediately before exposure to high $\mathrm{CO}_{2}$ and another five after storage at $20^{\circ} \mathrm{C}$ for $7 \mathrm{~d}$. From each slice, cortical plugs were taken and bulked together $(5-8 \mathrm{~g})$, weighed, placed in a $12-\mathrm{mL}$ screw-cap test tube, and immediately stored at $-20^{\circ} \mathrm{C}$.

For ethanol, acetaldehyde, and ethyl acetate determinations, each test tube was warmed for $1 \mathrm{~h}$ in a water bath at $65^{\circ} \mathrm{C}$ (Beaulieu et al., 1997). A $1-\mathrm{mL}$ headspace sample was taken from the tube and injected into a gas chromatograph (model GC-8A; Shimadzu, Columbia, Md.) fitted with a flame ionization detector $\left(250{ }^{\circ} \mathrm{C}\right)$ and a glass column $(2 \mathrm{~mm} \times 1.8 \mathrm{~m})$ containing 5\% Carbowax on 60/80 Carbopack (Supelco, Bellefonte, $\mathrm{Pa}$.), at $85^{\circ} \mathrm{C}$. Tissue concentration was calculated using a standard curve, generated by injecting a 1 -mL headspace sample into the gas chromatograph from warmed 5-mL standard solutions of known concentrations in 12-mL test tubes. All values are reported on a fresh-weight basis. 
For the two orchards harvested at 190 and 210 DAFB, data were analyzed as a split-split plot design, with orchard analyzed as the main effect, harvest date as the split, treatment as a further split, and using the individual plots as replicates. Treatments were defined as the initial (before $\mathrm{CO}_{2}$ exposure) sample plus the combination of each $\mathrm{CO}_{2}$ partial pressure $\times$ exposure time. Variation due to orchard site at 190 DAFB was analyzed separately and, in this case, each $\mathrm{CO}_{2}$ partial pressure exposure time was analyzed independently. All tissue concentration data were $\log$ transformed to stabilize the variance before each analysis of variance (ANOVA).

\section{Results and Discussion}

Harvest date. Orchard had a significant effect on area of flesh browning and acetaldehyde concentration ( $P=0.04$ and 0.03 , respectively) (see below), but not on ethanol and ethyl acetate concentrations. There were no significant interactions between harvest date and treatment on flesh browning or tissue concentrations of ethanol, acetaldehyde, and ethyl acetate, so data were pooled across the two orchards at 190 and 210 DAFB.

Flesh browning increased with increasing time of exposure to high $\mathrm{CO}_{2}$ partial pressures and was greater for the later harvest and the longer exposure times (Fig. 1A). After $3 \mathrm{~d}$, more browning was observed in fruit in the 50 $\mathrm{kPa}$ than in the $20 \mathrm{kPa}$ treatment, but browning was greatest after $7 \mathrm{~d}$ at $20 \mathrm{kPa} \mathrm{CO}$. These results are consistent were those reported earlier for 'Fuji' apples grown in California (Volz et al., 1998). Browning was not observed in fruit stored in air.

Ethanol (Fig. 1B) and acetaldehyde (Fig. 1C) concentrations increased within 1 to $3 \mathrm{~d}$ following exposure to high $\mathrm{CO}_{2}$, and continued to increase with increasing exposure time. Production of these compounds was greater after $3 \mathrm{~d}$ at $50 \mathrm{kPa}$ than at $20 \mathrm{kPa} \mathrm{CO}_{2}$. For 50 $\mathrm{kPaCO}_{2}$, ethanol and acetaldehyde concentrations had increased 100- and 10-fold, respectively, similar to the increases reported for 'Newtown Wonder' apples exposed to similar gas partial pressures and exposure times at 15 ${ }^{\circ} \mathrm{C}$ (Thomas, 1925). Storage in air at $20^{\circ} \mathrm{C}$ for $7 \mathrm{~d}$ did not affect tissue concentrations of ethanol, acetaldehyde, or ethyl acetate (data not shown). $\mathrm{CO}_{2}$ may stimulate ethanol and acetaldehyde production through its positive effects on activation and/or transcription of the fermentation enzymes, pyruvate decarboxylase (EC 4.1.1.1), and alcohol dehydrogenase (EC 1.1.1.1), as well as through accumulation of pyruvate (Ke et al., 1993).

Later harvested fruit accumulated more ethanol and acetaldehyde than earlier harvested fruit at similar $\mathrm{CO}_{2}$ partial pressures and exposure times (Fig. $1 \mathrm{~B}$ and C). A similar harvest date effect was found with peach and pear fruit when exposed to very low $\mathrm{O}_{2}$ partial pressures (Ke et al., 1993). Fruit resistance to diffusion of $\mathrm{CO}_{2}$ and $\mathrm{O}_{2}$ can be influenced by both cultivar and harvest date (Gran and Beaudry, 1993; Park et al., 1993; Rajapakse et al., 1990), thereby affecting internal gas com- position within the fruit and the tissue's response to external atmospheres. However, there is little influence of harvest date on skin resistance to $\mathrm{CO}_{2}$ in 'Fuji' (Volz et al., 1998). Greater production of ethanol and acetaldehyde at a more advanced harvest date in 'Fuji' may reflect increased sensitivity of the tissue to high $\mathrm{CO}_{2}$.

Ethyl acetate concentrations, while $<1 \%$ of those of ethanol and acetaldehyde before exposure, increased to $>70$ times its initial level on exposure to $\mathrm{CO}_{2}$. Alcohols are converted to esters by alcohol O-acetyltransferase (EC 2.3.1.84), and high concentrations of ethanol, the immediate precursor of ethyl acetate, may stimulate ethyl acetate production (Ke et al., 1993). While not all apple cultivars show a concurrent increase of ethyl acetate with increasing ethanol concentrations, this has also been observed in 'Fuji's' parent, 'Delicious', and half-sibling, 'Empire' (Blanpied and Jozwiak, 1993).

Orchard variability. Tissue response to increasing exposure time for the two $\mathrm{CO}_{2}$ atmospheres for fruit from all five orchards harvested at 190 DAFB was similar to those described above (Fig. 1). Differences were evident among orchards in the extent of browning and production of ethanol, acetaldehyde, and ethyl acetate, although these were not always consistent between the two $\mathrm{CO}_{2}$ partial pressures. For instance, one orchard had greater area of flesh browning and higher ethanol and acetaldehyde production than another orchard under $50 \mathrm{kPa} \mathrm{CO}_{2}$, but this relationship was reversed under $20 \mathrm{kPa} \mathrm{CO}_{2}$.

Relationships between tissue concentrations of ethanol, acetaldehyde, and ethyl acetate and flesh browning were developed using data from all orchards and harvest dates. When orchard averages at each harvest date were considered $(n=7)$, acetaldehyde concentrations increased with increasing area of flesh browning after $7 \mathrm{~d}$ exposure to $20 \mathrm{kPa} \mathrm{CO}_{2}$ or $3 \mathrm{~d}$ exposure to $50 \mathrm{kPaCO}_{2}(r=0.88, P=0.01$ and $r=0.82, P=0.03$, respectively). For

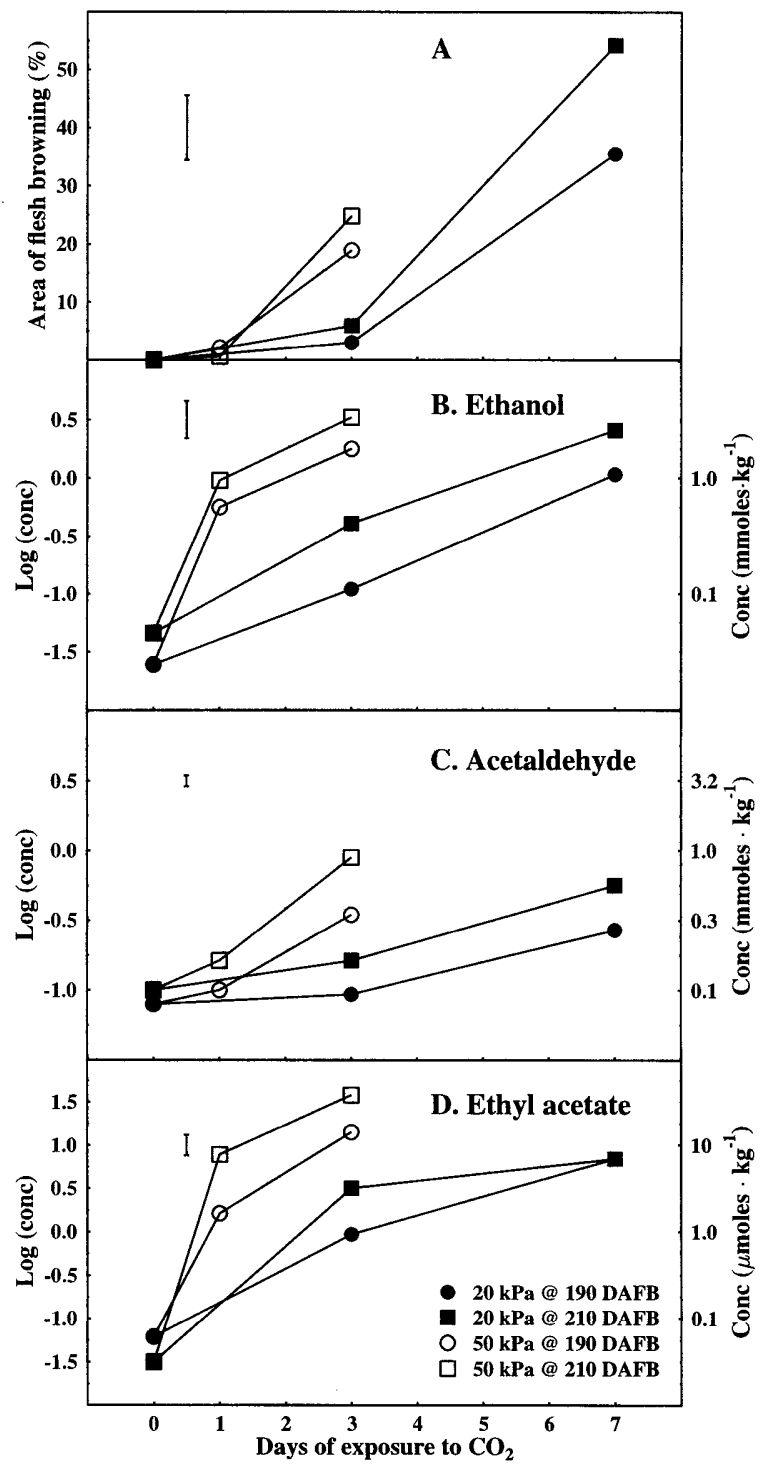

Fig. 1. Effects of time of exposure to 20 and $50 \mathrm{kPa} \mathrm{CO}$ on area of flesh browning (A) and tissue concentrations of ethanol (B), acetaldehyde (C), and ethyl acetate (D) in 'Fuji' apples harvested at 190 and 210 DAFB. Data pooled over two orchards and, for tissue concentrations, log transformed before ANOVA. $\operatorname{Bar}=\operatorname{LSD}(P=0.05)$. 
individual fruit within any one orchard $(n=$ $10)$, concentrations of acetaldehyde also increased with increasing area of flesh browning $(r>0.56, P<0.05)$ after $7 \mathrm{~d}$ at $20 \mathrm{kPa} \mathrm{CO}_{2}$ for all sites except one at $190 \mathrm{DAFB}$, and in four sites after $3 \mathrm{~d}$ at $50 \mathrm{kPa} \mathrm{CO}$. Ethanol concentrations were also correlated with flesh browning for individual orchards $(r=0.79, P=0.04)$, and for individual fruit within an orchard at six sites $(r>0.66, P<0.05)$ after $7 \mathrm{~d}$ at $20 \mathrm{kPaCO}_{2}$, but not after $3 \mathrm{~d}$ at $50 \mathrm{kPa} \mathrm{CO}_{2}$. Ethyl acetate concentrations were not correlated with flesh browning across orchards or for individual fruit at any one site for either $\mathrm{CO}_{2}$ atmosphere $(P>0.09)$. Values and ranges of values in flesh browning among orchards were considerably less for the shorter than for the longer exposure times for each $\mathrm{CO}_{2}$ partial pressure [e.g., $2 \%$ to $11 \%(3 \mathrm{~d})$ vs. $28 \%$ to $62 \%(7 \mathrm{~d})$ for $20 \mathrm{kPa}$ ]. That flesh browning and tissue concentrations of each compound were not correlated $(P>$ 0.23 ) for the shorter $\mathrm{CO}_{2}$ exposure times is therefore not suprising.

In 'Newtown Wonder', acetaldehyde was also associated with $\mathrm{CO}_{2}$-induced flesh browning (Thomas, 1925) but at much higher concentrations on a fresh-weight basis ( $>2.2$ $\left.\mathrm{mmol} \cdot \mathrm{kg}^{-1}\right)$ than those concentrations found in our study $\left(<2.2 \mathrm{mmol} \cdot \mathrm{kg}^{-1}\right)$. Acetaldehyde concentrations that are toxic vary considerably among different plant species (Perata and Alpi, 1993), but variation in toxicity for different cultivars within a species is unknown.

Despite these significant relationships, accumulation of ethanol and/or acetaldehyde in cortical tissue, as induced by $\mathrm{CO}_{2}$, may not be the sole causal agent in inducing browning, and other factors could be involved. Scatter graphs showing the association between flesh browning and acetaldehyde (Fig. 2), ethanol, or ethyl acetate concentrations (data not shown) for individual orchards indicate that production of each compound, relative to flesh browning area, was greater at $50 \mathrm{kPa}$ than at $20 \mathrm{kPa}$
$\mathrm{CO}_{2}$. For individual fruit, relationships beween compounds and browning were also dependent upon $\mathrm{CO}_{2}$ partial pressure. For instance, at $210 \mathrm{DAFB}$, acetaldehyde and ethanol concentrations $\left(0.32\right.$ and $3.0 \mathrm{mmol} \cdot \mathrm{kg}^{-1}$, respectively) were greater in fruit exposed to $50 \mathrm{kPa}$ for $3 \mathrm{~d}$ that did not brown, than in those showing $20 \%$ internal browning after exposure to $20 \mathrm{kPa}$ for the same period. There may be some temporal differences in the $\mathrm{CO}_{2}$ induction of the fermentative pathway and that of visible browning symptoms for 'Fuji'. Similarly, acetaldehyde and ethanol production in pear relative to browning was greater under $50 \mathrm{kPa} \mathrm{CO}_{2}$ than under $20 \mathrm{kPaCO}_{2}$ after $6 \mathrm{~d}$ exposure at $15^{\circ} \mathrm{C}$ ( $\mathrm{Ke}$ et al., 1990). Exposure of 'Fuji' apple fruit to exogenous acetaldehyde or ethanol may prove useful in understanding the possible relationship between these compounds and flesh damage.

In apple and pear, $\mathrm{CO}_{2}$ inhibits the activity of succinic dehydrogenase (EC 1.3.99.1), which converts succinic acid to fumaric acid (Frenkel and Patterson, 1973; Knee, 1973). High succinic acid concentrations are associated with $\mathrm{CO}_{2}$-induced injury in apple (Hulme, 1956). Initial measurements conducted in our laboratory have also shown succinic acid concentrations to be higher in browned than nonbrowned 'Fuji' fruit stored under high $\mathrm{CO}_{2}$ atmospheres (unpublished data). However, at similar levels of flesh browning, concentrations were much greater under $50 \mathrm{kPa} \mathrm{CO}$ than under $20 \mathrm{kPa} \mathrm{CO}_{2}$. Exposure to high $\mathrm{CO}_{2}$ may also reduce ATP: ADP ratios and thus the energy supply needed for maintenance of cellular processes (Lange and Kader, 1997), leading to loss of membrane function and compartmentalization (Chervin et al., 1996).

Whatever the mechanism by which $\mathrm{CO}_{2}$ induces flesh browing in 'Fuji' apples, it is probably the same in fruit exposed to very high $(\geq 20 \mathrm{kPa}) \mathrm{CO}_{2}$ atmospheres as in those exposed to lower concentrations at lower tem-

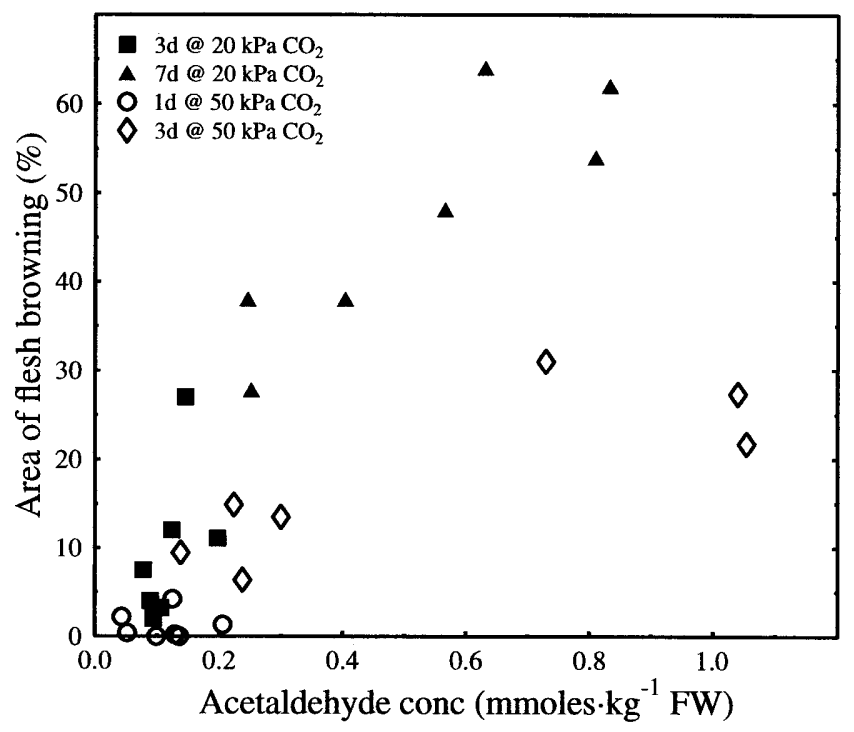

Fig. 2. Scatter plot of tissue acetaldehyde concentration and area of flesh browning after fruit exposure to 20 ( 3 and $7 \mathrm{~d})$ or $50 \mathrm{kPaCO}_{2}(1$ and $3 \mathrm{~d})$. Each point represents the average value for an individual orchard at 190 or 210 DAFB. peratures for longer periods, such as that used in CA. Visible symptoms of flesh browning are identical, and preharvest conditions affect flesh browning responses to $\mathrm{CO}_{2}$ exposure under both $\mathrm{CA}$ conditions and under high $\mathrm{CO}_{2}$ atmospheres at ambient temperatures (Volz et al., 1998). However, flesh browning in response to $\mathrm{CO}_{2}$ occurs much more rapidly under high $\mathrm{CO}_{2}(1-3 \mathrm{~d})$ than in $\mathrm{CA}(14-56 \mathrm{~d}$; unpublished data).

In conclusion, the area of flesh browning increased and fermentative production of ethanol, acetaldehyde, and ethyl acetate were stimulated by exposure of 'Fuji' fruit to high $\mathrm{CO}_{2}$ atmospheres. While some positive correlations were found between flesh browning and tissue acetaldehyde and ethanol concentrations, the relationship between concentrations and area of browning differed for the two $\mathrm{CO}_{2}$ atmospheres. The causal mechanism of $\mathrm{CO}_{2}$ injury and the potential involvement of acetaldehyde and ethanol in 'Fuji' apple remain to be elucidated.

\section{Literature Cited}

Beaulieu, J.C., G. Peiser, and M.E. Saltveit, Jr. 1997. Acetaldehyde is a causal agent responsible for ethanol-induced ripening inhibition in tomato fruit. Plant Physiol. 113:31-439.

Blanpied, G.D. and Z.J. Jozwiak. 1993. A study of some orchard and storage factors that influence the oxygen threshold for ethanol accumulation in stored apples. Proc. 6th Intl. Controlled Atmosphere Res. Conf. 1:78-86.

Bramlage, W.J., P.H. Bareford, G.D. Blanpied,D.H. Dewey, S. Taylor, S.W. Porritt, E.C. Lougheed, W.H. Smith, and F.S. McNicholas. 1977. Carbon dioxide treatment for 'McIntosh' apples before CA storage. J. Amer. Soc. Hort. Sci. 102:658-662.

Chervin, C., C.J. Brady, B.D. Patterson, and J.D. Faragher. 1996. Could studies on cell responses to low oxygen levels provide improved options for fruit storage and disinfestation? Postharvest Biol. Technol. 7:289-299.

Frenkel, C. and M.E. Patterson. 1973. Effect of $\mathrm{CO}_{2}$ on activity of succinic acid dehydrogenase in 'Bartlett' pears during cold storage. HortScience 8:395-396.

Gran, C.D. and R.M. Beaudry. 1993. Modified atmosphere packaging determination of lower oxygen limits for apple fruit using respiratory quotient and ethanol accumulation. Proc. 6th Intl. Controlled Atmosphere Res. Conf. 2:54 62.

Grant, J., B. Mitcham, B. Biasi, and S. Chinchiolo. 1996. Late harvest, high $\mathrm{CO}_{2}$ storage increases internal browning of 'Fuji' apples. Calif. Agr. 50:26-29.

Hulme, A.C. 1956. Carbon dioxide injury and the presence of succinic acid in apples. Nature 178:218-219.

Kader, A.A. 1986. Biochemical and physiological basis for effects of controlled and modified atmospheres on fruits and vegetables. Food Tech. 40:99-104.

Ke, D. and A.A. Kader. 1992. External and internal factors influence fruit tolerance to low-oxygen atmospheres. J. Amer. Soc. Hort. Sci. 117:913918.

Ke, D., M. Mateos, and A.A. Kader. 1993. Regulation of fermentation metabolism in fruits and vegetables by controlled atmospheres. Proc. 6th Intl. Controlled Atmosphere Res. Conf. 1:6377. 
Ke, D., H. van Gorsel, and A.A. Kader. 1990. Physiological and quality responses of Bartlett pears to reduced $\mathrm{O}_{2}$ and enhanced $\mathrm{CO}_{2}$ levels and storage temperature. J. Amer. Soc. Hort. Sci. 115:435-439.

Knee, M. 1973. Effects of controlled atmosphere storage on respiratory metabolism in apple fruit tissue. J. Sci. Food Agr. 24:12891298.

Kupferman, E. 1997. Controlled atmosphere storage of apples. Proc. 7th Intl. Controlled Atmosphere Res. Conf. 2:1-30.

Lange, D.L. and A.A. Kader. 1997. Elevated carbon dioxide exposure alters intracellular $\mathrm{pH}$ and energy charge in avocado fruit tissue. J. Amer. Soc. Hort. Sci. 122:253-257.

Lidster, P.D., G.D. Blanpied, and R.K. Prange. 1990. Controlled-atmosphere disorders of commercial fruits and vegetables. Agr. Can. Publ. 1947/E, Communications Branch, Agriculture Canada, Ottawa.
Meheriuk, M. 1977. Treatment of 'Golden Delicious' apples with $\mathrm{CO}_{2}$ prior to $\mathrm{CA}$ storage. Can. J. Plant Sci. 57:467-471.

Park, Y.M., G.D. Blanpied, Z. Joswiak, and F.W. Liu. 1993. Postharvest studies of resistance to gas diffusion in McIntosh apples. Postharvest Biol. Technol. 2:329-339.

Patterson, M.E. and W.C. Nichols. 1988. Metabolic responses of 'Delicious' apples to carbon dioxide in anoxic and low-oxygen environments. HortScience 23:866-868.

Perata, P. and A. Alpi. 1993. Plant responses to anaerobiosis. Plant Sci. 93:1-17.

Pesis, E., C. Ampunpong, B. Shusiri, and E.W. Hewett. 1994. Enhancement of ethylene and $\mathrm{CO}_{2}$ production in apple fruit following shortterm exposure to high $\mathrm{CO}_{2}$. Postharvest Biol. Technol. 4:309-319.

Rajapakse, N.C., N.H. Banks, E.W. Hewett, and D.J. Cleland. 1990. Development of oxygen concentration gradients in flesh tissues of bulky plant organs. J. Amer. Soc. Hort. Sci. 115:793-797.

Smagula, J.M. and W.J. Bramlage. 1977. Acetaldehyde accumulation: Is it a cause of physiological deterioration of fruits? HortScience 12:200 203.

Thomas, M. 1925. The controlling influence of carbon dioxide. V. A quantitative study of the production of ethyl alcohol and acetaldehyde by cells of higher plants in relation to concentration of oxygen and carbon dioxide. Biochem. J. 6:927-947.

Thomas, M. 1929. The production of ethyl alcohol and acetaldehyde by apples in relation to the injuries occurring in storage. 1 . Injuries to apples occurring in the absence of oxygen and in certain mixtures of carbon dioxide and oxygen Ann. Appl. Biol. 16:444-457.

Volz, R.K., W.V. Biasi, J.A. Grant, and E.J. Mitcham 1998. Prediction of controlled atmosphere-induced flesh browning in 'Fuji' apple. Postharvest Biol. Technol. 13:97-107. 